\title{
PENINGKATAN PENDAPATAN KELOMPOK TANI PADI ORGANIK MELALUI PROGRAM MANDIRI BENIH DI DESA KETAPANG KECAMATAN SUSUKAN SEMARANG
}

\author{
Supriyadi ${ }^{11,}$ Sumani ${ }^{2),}$ Purwanto ${ }^{3)}$ dan Mustofa ${ }^{4)}$ \\ Koordinator Jaminan Mutu Pengabdian LPPM UNS Solo, supriyadi_uns@yahoo.com \\ 2,3) Prodi Ilmu Tanah, Fakultas Pertanian, UNS \\ 4) Kelompok Tani Al Barokah, Ketapang Sususkan Semarang
}

\begin{abstract}
Background, excessive exploitation of paddy land in the long term without the addition of organic matter have resulted in soil become damaged. To meet the needs of food (rice) healthy and improve the functioning of the land, then there is no best alternative except development of organic farming systems. To be able to implement a system of organic farming, it is necessary to aplication of seed quality assurance. IbPUD activities carried out ini the village Ketapang, local village government has formed group of paddy organic farmers, but due to constraints in the available of seed rice organic. The purpose, carry out assistance to Farmers and Farmers Group in the establishment of the sources of seed organic rice and the acquisition of organic certification. The method, is Focus Group Discussion which emphasizes dialogue interpersosnal and mentoring. The program is implementing educational methods that involve the active participation of the participants from the three (3) groups of paddy organic farmers partners in Ketapang. The training was held in the form of: (1) seed rice breading management trainin, (2) training of organic rice management with the use of local waste and can be as alternative of organic fertilizers, and (3) training buines management.Results, an increasing number of farmers' groups who implement sources of seed organic rice of 4 (four) varietas (Mentik Susu, Mentik Wangi, Hitam Arang and Merah Anoman) to 3 farmer groups (15Ha). In conclusion, most members of the Farmers Group AlBarokah have felt: (a) the benefit of the treatment of organic in terms of soil quality and the products of organic rice and its by-products, (b) an increase in value-added organic products and farmers' income, (c) the importance of maintaining paddy according to its function, (d) have become independent farmers in organic rice cultivation.
\end{abstract}

Keywords: Organic farming systems, Organic certification, Interpersonal dialogue, 


\begin{abstract}
ABSTRAK
Latar belakang, eksploitasi tanah sawah yang berlebihan dalam jangka waktu lama tanpa penambahan bahan organik telah mengakibatkan tanah menjadi rusak. Untuk mencukupi kebutuhan pangan (padi) yang sehat dan meningkatkan fungsi tanah, maka tidak ada alternatif terbaik kecuali pengembangan sistem pertanian organik. Untuk dapat melaksanakan sistem pertanian padi organik, maka diperlukan ketersedian bibit padi organik. Untuk mengembangkan kemandirian sumber benih padai organik diperlukan adanya kepedulian dan dukungan dari berbagai pemangku kebijakan, Perguruan Tinggi dan Lembaga Sertifikasi produk organik. Untuk mewujudkan program sertifikasi produk organik, maka sangat diperlukan keberadaan program IbPUD (Ipteks bagi Produk Unggulan Daerah). Tujuan, melaksanakan IbPUD terhadap Kelompok Tani dan Gabungan Kelompok Tani dalam menentukan penetapan sumber benih padi organik dan perolehan sertifikasi organik. Metode, FGD yang mengedepankan dialog interpersosnal, pendampingan. Hasil, disepaki ada 4 macam varietas yang dikembangkan (Mentik Susu, Mentik Wangi, Hitam Arang dan Merah Anoman) jumlah kelompok tani yang melaksanakan 3 (tiga) kelompok tani (luas $15 \mathrm{Ha}$ ). Simpulan, sebagian besar anggota Gabungan Kelompok Tani Al-Barokah telah merasakan: (a) manfaatan perlakuan organik dari segi kualitas tanah dan produk padi organik serta produk sampingannya, (b) adanya peningkatan nilai tambah produk organik dan pendapatan petani, (c) pentingnya mempertahankan sawah sesuai fungsinya, (d) telah menjadi petani yang merdeka dalam budidaya padi organik.
\end{abstract}

Kata kunci: Sistem pertanian organik, Sertifikasi organik, Dialog interpersonal. 


\section{PENDAHULUAN}

Sistem Pertanian Organik adalah sistem manajemen produksi yang holistik untuk meningkatkan dan mengembangkan kesehatan agroekosistem, termasuk keragaman hayati, siklus biologi, dan aktivitas biologi tanah. Pertanian organik menekankan penerapan praktekpraktek manajemen yang lebih mengutamakan penggunaan input dari limbah kegiatan budidaya di lahan, dengan mempertimbangkan daya adaptasi terhadap keadaan/kondisi setempat dan bertujuan untuk memelihara keseimbangan ekosistem secara alami, mengoptimalkan kesehatan dan produktivitas yang berkelanjutan (Permentan Nomor 64/Permentan /OT.140/5/2013 Tentang Sistem Pertanian Organik; Standar Nasional Indonesia (SNI) 6729:2013 Tentang Sistem Pertanian Organik), IASA (1990), FAO (1999), Alimoeso (2009) dalam Cahyani (2010)].
Sebagai negara yang dianugerahi kekayaan keanekaragaman hayati tropika yang unik, kelimpahan sinar matahari, air dan tanah, serta budaya masyarakat yang menghormati alam, Indonesia berpotensi dan mempunyai modal dasar yang besar untuk mengembangkan sistem pertanian organik. Di lain pihak, kebanyakan petani di Indonesia mengalami kesulitan untuk mendapatkan saprotan pada saat yang tepat, sehingga diperlukan suatu bahan alternatif lain yaitu bahan alami seperti pupuk alam atau pupuk hayati serta pestisida nabati. Kedua fenomena tersebut mengarah ke satu titik yang sama yaitu pada kegiatan budidaya pertanian organik [Reijntjes et al (1992), Atmojo (2003), Iqbal (2008)].

Pemerintah Indonesia, telah melakukan upaya dalam pengembangan produk organik, walaupun masih belum memenuhi secara keseluruhan keinginan pelaku usaha terutama terkait dengan 
pengakuan jaminan keorganikan di tingkat regional maupun internasional. Namun demikian pada bulan Mei 2013, telah ditetapkan Peraturan Menteri Pertanian No.64 tentang "Sistem Pertanian Organik" yang diberlakukan secara nasional tahun 2014. Pelaku usaha yang ingin mengajukan sertifikasi, untuk menjamin integritas keorganikan produk, harus mengacu pada Peraturan Menteri tersebut, untuk kemudian disertifikasi oleh Lembaga Sertifikasi Organik (LSO).

Di dalam UU No. 17 tahun 2007 tentang RPJMN Tahun 2005-2025, peningkatan nilai tambah dan daya saing produk pertanian menjadi kata kunci RPJMN sebagaimana visi Kementerian Pertanian, yaitu "Terwujudnya pertanian industrial unggul, berkelanjutan yang berbasis lokal untuk meningkatkan kemandirian pangan, nilai tambah, eksport dan peningkatan kesejahteraan petani". Hal ini sesuai dengan kabinet kerja pemerintahan Jokowi-JK 2015-2019 yang tertuang dalam nawacita yaitu menciptakan 1000 desa mandiri organik.

Pengembangan sistem mutu pangan organik termasuk proses sertifikasi organik merupakan tanggung jawab bersama para pemangku kepentingan. Pemangku kepentingan yang dimaksud adalah:

(a) Pemerintah, (b) Pelaku Usaha (Operator Pertanian Organik), (c) Distributor, (d) Konsumen, (e) Lembaga Sertifikasi Pertanian Organik (LSPO). Adapun lembaga yang memiliki otoritas dalam melaksanakan verifikasi atau registrasi pangan organik adalah LPSO yang telah diakreditasi Komite Akreditasi Nasional (KAN).

Pelaku usaha agribisnis di Indonesia sebagian besar merupakan pelaku usaha berskala kecil, sehingga penerapan sistem jaminan mutu pangan organik menjadi kendala tersendiri, sehingga menerapkan ICS secara berkelompok. Pada tahun 2010, Direktorat Jenderal Pengolahan dan Pemasaran Hasil Pertanian telah 
menghasilkan pedoman sistem kendali Internal (ICS) yang perlu disosialisasikan secara terus menerus dan berkelanjutan kepada para penerima manfaat.

Peran perguruan tinggi dalam pemberdayaan ini sebagaimana yang dijelaskan dalam Peraturan Pemerintah RI No 60 Tahun 1999 pasal 3 ayat 1 yang menyatakan bahwa perguruan tinggi menyelenggarakan pendidikan tinggi, penelitian dan pengabdian kepada masyarakat. Oleh karena itu keterlibatan perguruan tinggi dalam program pembinaan pertanian organik merupakan wujud tugas pengabdian kepada masyarakat. Mengingat ICS bagi kelompok tani merupakan sesuatu yang baru, maka untuk mewujudkannya diperlukan upaya pendampingan dari Perguruan Tinggi. Adapun yang dimaksud pendampingan dalam kegiatan ini sangat terkait dengan pemberian kekuasaan (power) dan pengembangan kapasitas kepada penerima manfaat [lfe et al (2008), Soetomo (2009 dan 2011)].

Perguruan Tinggi berperan sebagai Agen (aktor) pemberdaya. Agen pemberdaya sebagai pemberi kekuasaan dan pengembangan kapasitas masyarakat (petani) dapat berasal dari internal kelompok tani. Peran Agen (aktor) pemberdaya lebih ditekankan sebagai pemungkin terjadinya proses pemberian kekuasaan dan pengembangan kapasitas bagi penerima manfaat, sehingga dapat menentukan masa depannya sendiri (Soetomo, 2009 dan 2011). Agen pemberdaya harus mampu menempatkan diri pada posisi yang paling tepat, sehingga proses pemberian kekuasaan dan pengembangan kapasitas kepada penerima manfaat dapat terjadi (Mardikanto, 2009 dan 2010). Mengingat tidak ada satupun Agen pemberdaya yang mampu melaksanakan semuanya (Ife et al., 2008 dan Mardikanto, 2010), maka diperlukan jejaring kemitraan berbagai pemangku kepentingan 
[Kallas et al (2009), Sharifi et al., (2010), Oleas., (2010)].

Persyaratan teknis produk pangan organik harus sesuai dengan standart regulasi teknis yang ditentukan oleh Departemen Pertanian (2008) mencakup (a) budidaya pertanian, (b) pengolahan, penyimpanan, penanganan dan transportasi produk pangan organik, (c) label, pelabelan dan informasi pasar. Tujuan kegiatan ini adalah melakukan pendampingan terhadap Poktan/Gapoktan agar mampu secara mandiri menerapkan sistem pertanian organik sehingga siap memperoleh sertifikat dari Lembaga Sertifikasi Organik (LSO) yang diakui pemerintah.

\section{METODE}

Program IbPUD ini merupakan kerjasama swakelola antara: (a) Direktorat Jenderal Pendidikan Tinggi Kemenristek dengan (b) Lembaga Penelitian dan Pengabdian Kepada Masyarakat Universitas Sebelas Maret. Pelaksanaan kegiatan pada bulan April sampai dengan bulan Oktober 2017. Adapun lokasi pelaksanaannya di Desa Ketapang, Kecamatan Susukan, Kabupaten Semarang, Propinsi Jawa Tengah.

Metode yang dilakukan dalam pendampingan ini adalah:

1. Dialog interpersonal, tentang kemanfaatan sertifikasi produk padi organik kepada: (a) Kepala Desa Susukan, (b) Para tokoh kunci kelompok tani yang bersedia terlibat dalam program sertifikasi pertanian organik Fokus Grup Diskusi (FGD), tentang kemanfaatan teknik produk benih padi organik kepada para anggota kelompok tani yang bersedia bergabung.

\section{Pendampingan}

Teknis, pembentukan struktur organisasi ICS dan pengenalan berbagai dokumen yang diperlukan serta cara pengisiannya.

3. Adapun tahapan pelaksanaannya meliputi: (a) 
rapat persiapan pelaksanaan, (b) koordinasi dengan Dinas Pertanian Provinsi/ Kabupaten Semarang, (c) pelaksanaan dan pendampingan di poktan/ gapoktan yang meliputi workshop dan pembuatan demo plot tanaman padi sebagai sumber benih unuk petani. Secara garis besar metode pendekatan yang digunakan adalah dengan pendekatan Community-based. Pedekatan community-besed dipilih karena keterlibatan dan peran serta masyarakat (mitra) dalam setiap tahapan sangat diperlukan, menerapkan pendekatan Program Tindak Partisipatif (Partisipatory Action Program) dari peserta pada seluruh kegiatan IbPUD meliputi : diskusi, kerja bengkel/studio, operasional lahan, pelatihan dan pendampingan (kelompok dan individu) dan demonstrasi lapangan (Gambar 1). Tahap
Pelaksanaan kegiatan IbPUD

(Tabel 1.) 


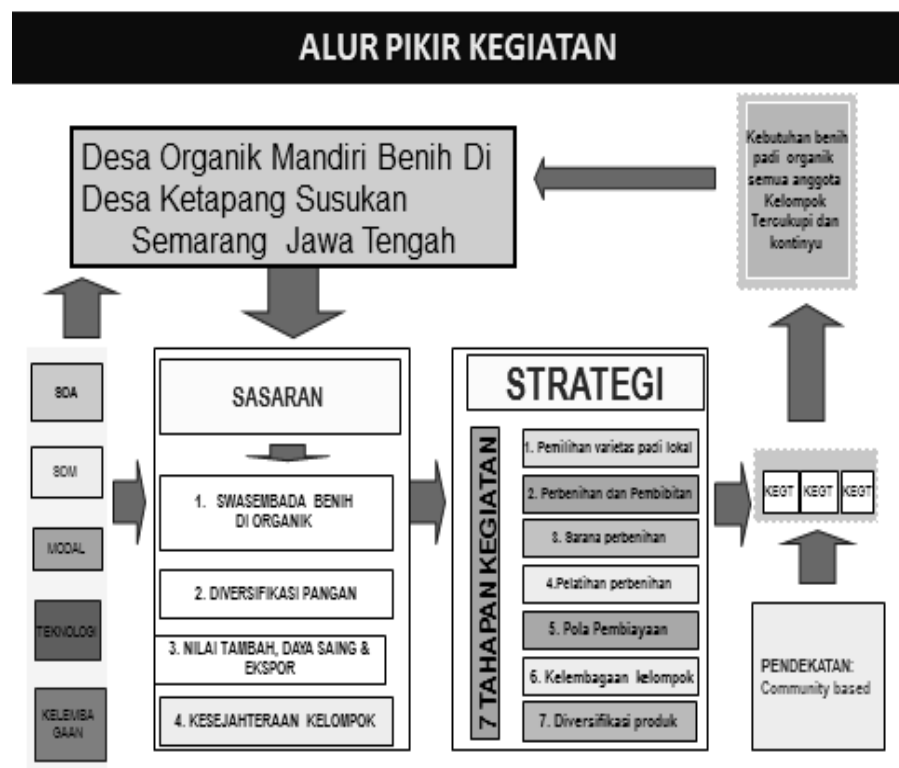

Gambar 1. Alur Pikir Kegiatan

Tabel 1. Tahap Pelaksanaan kegiatan IbPUD

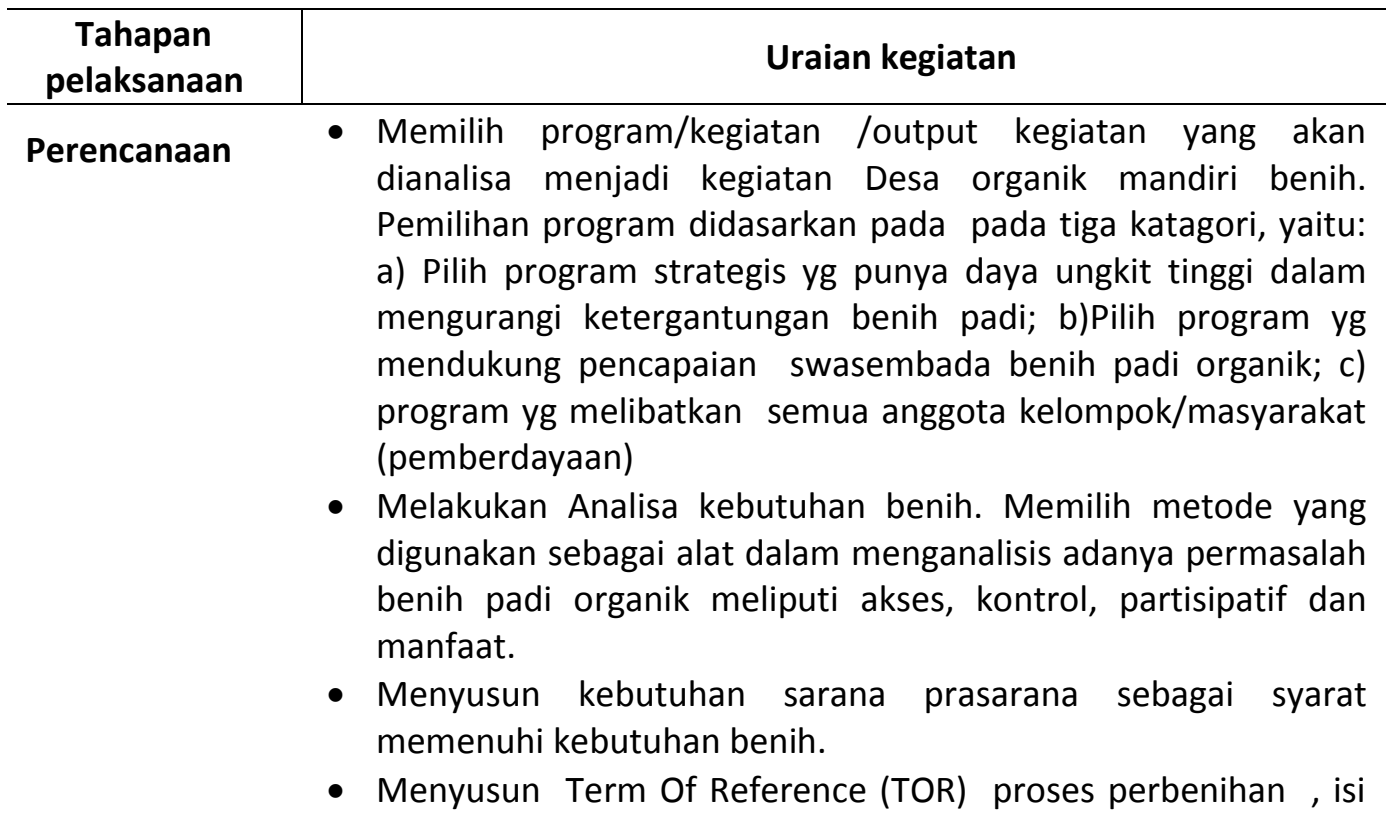




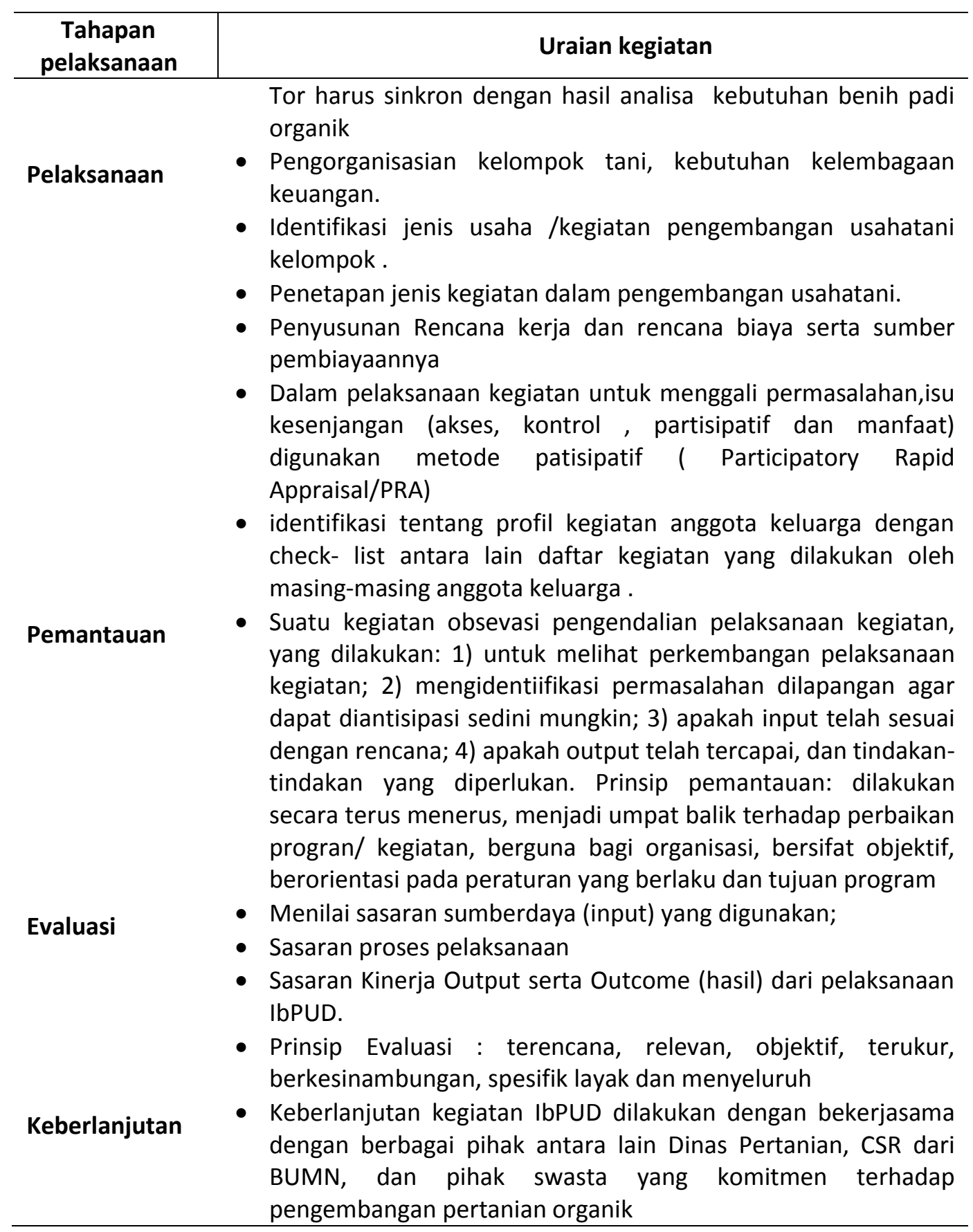


Partisipasi mitra dalam pelaksanaan kegiatan IbPUD, mitra secara aktif berpartisipasi secara aktif dalam seluruh kegiatan, dalam bentuk dana, sarana dan prasarana. Partisipasi mitra dalam pendanaan berupa inkind setiap tahun $\mathrm{Rp}$. 21.000.000,- yang diujudkan dalam bentuk ketersedian lahan untuk pembenihan dan penanaman padi organik masing-masing mitra 5 ha.

Secara umum pola hubungan kerja antar masingmasing mitra dalam kegiatan IbPUD sangat baik, hal ini terlihat misalnya antar UKM sering saling meminjam berbagai bahan dan peralatan. Misalnya pada saat salah satu mitra kekurangan bahan pupuk organik maka mitra yang lain akan mensuplai dan sebaliknya atau bahan-bahan yang lain (pestisida organik, bibit dll). Demikian pula dalam hal peralatan dan sarana antar UKM akan saling melengkapi, terutama dalam pemasaran produk.

\section{HASIL DAN PEMBAHASAN}

\section{Kelompok tani dan luasl Lahan sawah organik}

Tim IbPUD bersama

pengurus kelompok tani melakukan inspeksi dan pendataan yang dilakukan mengenai : 1) mendatangi petani mengenai nilai keorganikannya, 2) selalu menerima masukan - masukan dari anggota 3) melaporkan adanya pelanggaran pada kelompok tani, 4) melaporkan hasil inspeksi kepada TIM . Hasil inspeksi (Tabel 2) menunjukkan bahwa terdapat 125 ha lahan padi organic yang ada di wilayah desa Ketapang Kecmatan Sususkan Semarang. Berdasarkan dari hasil dari pendaftaran petani, didapatkan jumlah luasan lahan sementara yang yang digunakan untuk pengembangan padi organik mencapai luas 125.25 ha. Untuk mendukung pengembangan padi organik di butuhkan ketersedian sarana produksi yang memmadai terutama ketersedian benih yang berkualitas. 
Tabel 2. Daftar Kelompok Tani dan luas lahan sawah (ha) di Desa Ketapang

\begin{tabular}{cccc}
\hline Kelompok Tani & Organik & Konversi 2 & Konversi 1 \\
\hline Al-Barokah 1 & 4.277 & 1.043 & 1.4 \\
Al-Barokah 3 & 7.406 & 4.796 & 2.338 \\
Sunan Ampel & 6.789 & 0 & 0 \\
Dewi sri & 8.961 & 1.589 & \\
Ngudi Lestari & 3.9 & 9.32 & 2.43 \\
Sumber Rejeki & 0.95 & 9.3 & 5.75 \\
Mandiri & 0.25 & 9.05 & 7.3 \\
Walisongo & 8.885 & 2.28 & 2.575 \\
Al-Mazroah & 5.372 & 4.708 & 2.002 \\
Suko Maju & & 10.75 & 0.8 \\
Jumlah (ha) & $\mathbf{4 6 . 7 9}$ & $\mathbf{5 2 . 8 3 6}$ & $\mathbf{2 4 . 5 9 5}$ \\
\hline
\end{tabular}

Sumber: Diolah dari laporan kegiatan dan survey lapangan tahun 2016-2017 


\section{Pemilihan benih padi organik}

Banyak sekali benih padi saat ini beredar di pasaran. Hanya saja tidak pernah bisa memastikan apakan benih padi tersebut benar-benar berkualitas. Pasti pernah mengalami membeli benih padi bersertifikasi atau benih padi berlabel namun ketika panen hasilnya tidak seperti yang diharapkan. Ada cara yang bisa lakukan untuk mendapatkan benih padi kualitas terbaik, yaitu dengan membuat benih padi sendiri. Sebetulnya tidak sulit apabila mau membuat benih padi sendiri benih padi unggul organik. Penangkaran benih padi organik, sebagai benih penjenis (Breeder Seed) dan benih dasar (Foundation Seed) yang dilakukan oleh kelompok tani (Al-Barokah, Walisongo dan AlMazroah) yaitu padi Mentik Wangi, Mentik Susu, (Gambar 2) 

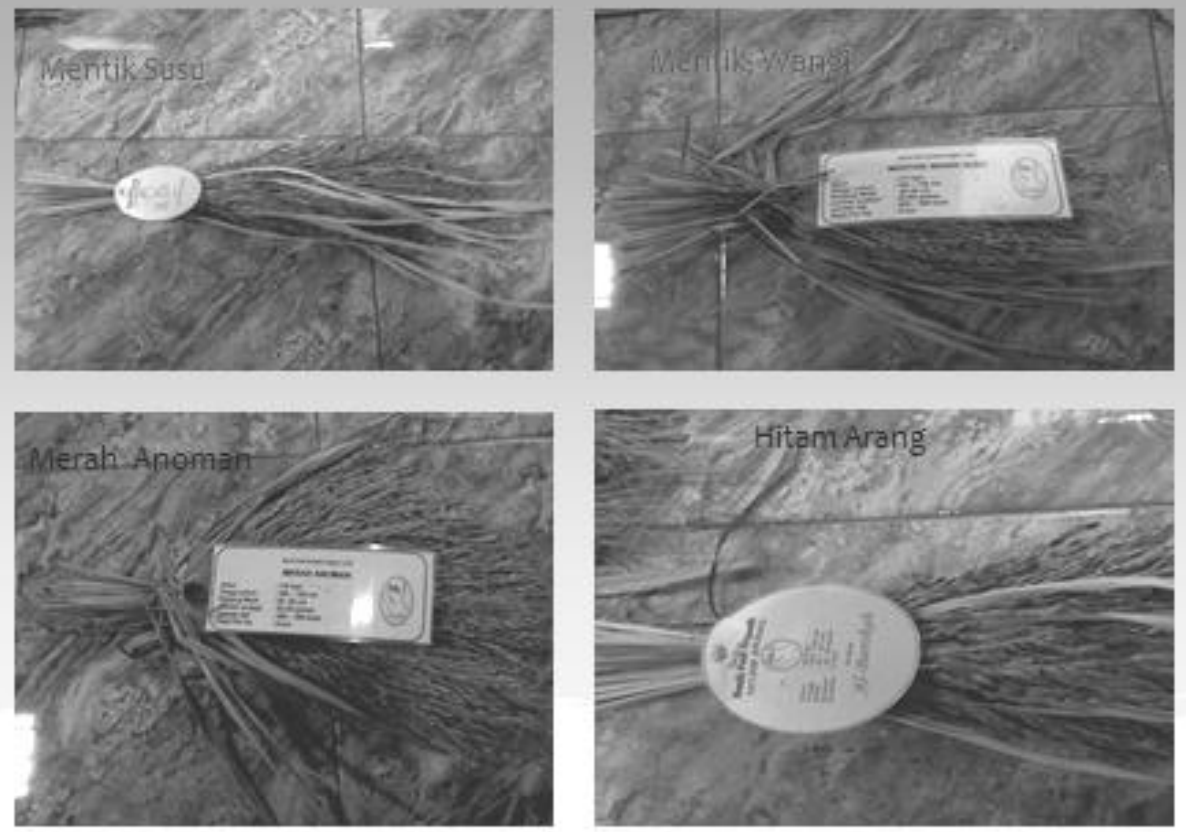

Gambar 2. Diskripsi varietas padi organik lokal 


\begin{abstract}
Syarat utama membuat benih padi unggul adalah harus memiliki benih padi berlabel putih, apabila kesulitan mendapatkan benih padi berlabel putih, bisa menggunakan benih padi berlabel ungu. Benih padi berlabel ungu bisa didapatkan di kios-kios pertanian. Sedangkan kebutuhan rata-rata adalah $25 \mathrm{~kg}$ benih untuk 1 ha lahan atau menyesuaikan dengan kebutuhan pembenihan berdasarkan luas lahan yang akan dikelola.
\end{abstract}

Selanjutnya, langkah kedua adalah menyiapkan lahan untuk menanam benih padi tersebut. Lahan persemaian benih padi harus terisolasi dengan tanaman padi yang lain agar kemurniannya terjaga. Jarak lahan persemaian dengan lahan tanaman padi yang lain minimal $10 \mathrm{~m}$. Bila kesulitan mendapatkan lahan yang mempunyai jarak ideal dengan lahan tanaman padi lainnya, dapat menanam di sekitar lahan tersebut tapi waktunya berbeda, sehingga waktu berbunganya tidak bersamaan untuk menghindari penyerbukan silang yang akan mengakibatkan penurunan kemurnian.

Sebelum benih label putih atau ungu disemai, sebaiknya seleksi dulu dengan menggunakan air garam atau air abu. Gunakan benih yang terendam dan benih terapung harus dibuang. Rendam dengan air bersih ditambah pupuk organic cair, selama 24 jam dan tiriskan selama 24 jam pula. Perhatikan bila calon akar belum ada 0,5 cm maka pemeraman bisa diperlama 24 jam lagi.

Lahan pesemaian disiapkan seperti biasa dengan luas kurang lebih $20 \%$ dari luas lahan yang akan dikelola. Cara pembuatan bibit seperti penanaman padi biasa. Pada saat pengolahan tanah taburkan kapur pertanian dolomit ditambah pupuk organik (cair atau padat). Cara penanaman benih padi unggul yang baik adalah harus memperhatikan jarak tanam, yaitu 
$20-25 \mathrm{~cm}$ dengan sistem tanam legowo 2 : 1 atau maksimal $4: 1$. Tanam harus umur muda, kurang dari 18-21 hari setelah semai. Saat penanaman juga jangan terlalu dalam. Gunakan cara tanam jiwir 2 - 3 batang per lubang.

Dalam pemeliharaan yang paling penting adalah pengairan berselang, yaitu pemberian air dan buang air sampai tanah agak mengering. Tanaman jangan selalu direndam air. Pemupukan mengunakan pupuk organik dan menambahkan urea $100 \mathrm{~kg} / \mathrm{ha}$ atau sesuaikan kebutuhan dengan menggunakan bagan warna daun. Pemupukan bisa diberikan 2 kali atau 3 kali.

Ketika tanaman benih padi unggul telah berbuah (keluar malai) maka perlu dilakukan penyortiran, hal ini berguna untuk meningkatkan kemurnian benih. Penyortiran dilakukan dengan cara membuang/ memangkas bulir-bulir padi yang berbeda varietasnya. Pemangkasan juga dilakukan terhadap jenis gulma yang sefamili dengan padi. Pemanenan benih padi unggul dilakukan jangan bersamaan dengan tanaman padi konsumsi. Hal ini bertujuan agar supaya benih tidak tercampur dengan benih lain. Gunakan sabit yang bergerigi dan taruh potongan malai pada terpal atau karung bekas. Pemanenan dilakukan saat padi menguning sekitar 90-95\%.

Penjemuran calon benih padi unggul sebaiknya tidak dilakukan di lantai jemur, melainkan harus diberi alas terpal atau anyaman bambu. Penjemuran sebaiknya dilakukan saat pagi hari sekitar jam 07.00 sampai jam 10.00 dan sore hari sekitar jam 14.30 sampai jam 17.00. Pengeringan sampai kadar air sekitar 14 - 12\%. Sebelum digunakan untuk benih sebaiknya benih padi unggul dilakukan stagnasi dulu, yaitu disimpan dalam karung sekitar $1-2$ minggu. Setelah proses stagnasi bibit padi unggul siap digunakan. 


\section{Demo Plot Tanaman Padi untuk}

\section{Sumber Benih}

Hasil FGD menyepakati bahwa : masing-masing kelompok tani menyediakan 5 ha lahan sawah untuk penanaman padi sebagai sumber benih padi organik, masingmasing kelompok tani menyusun dokumen permohonan sebagai produsen benih padi; dan perbaikan 3 (tiga) lumbung benih padi dan satu (1) rumah kompos. 


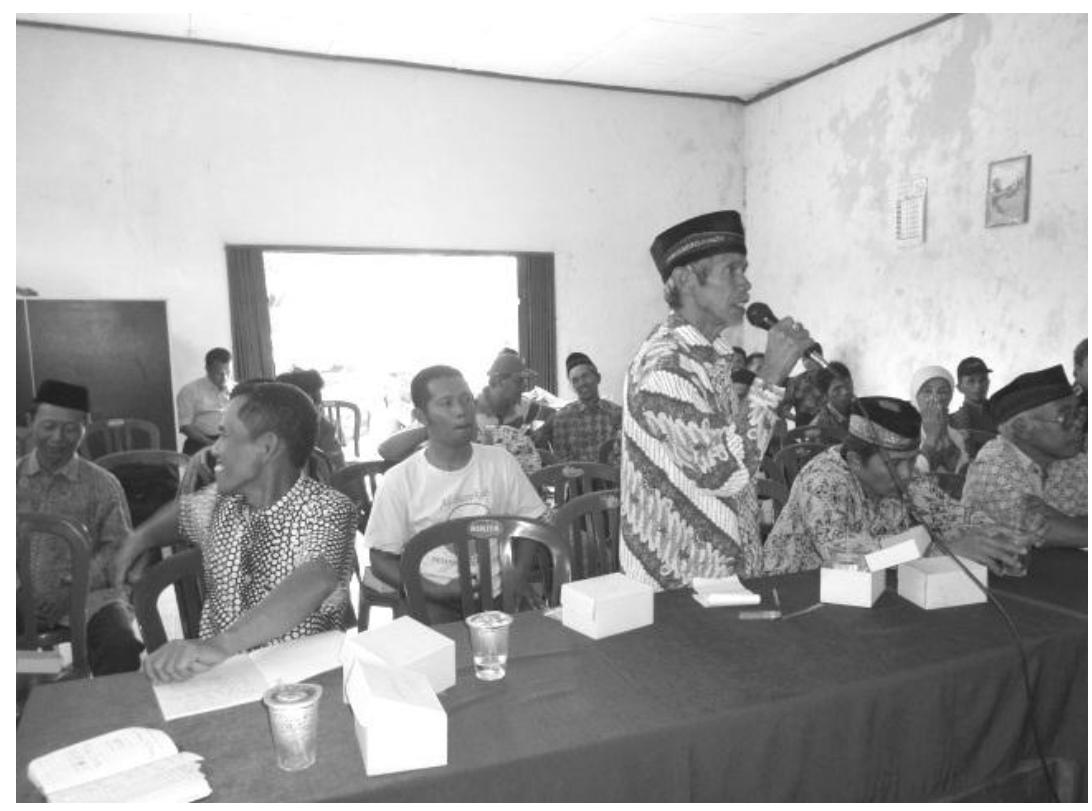

Gambar 3. FGD penentuan lokasi dan luas lahan penanaman benih padi organik

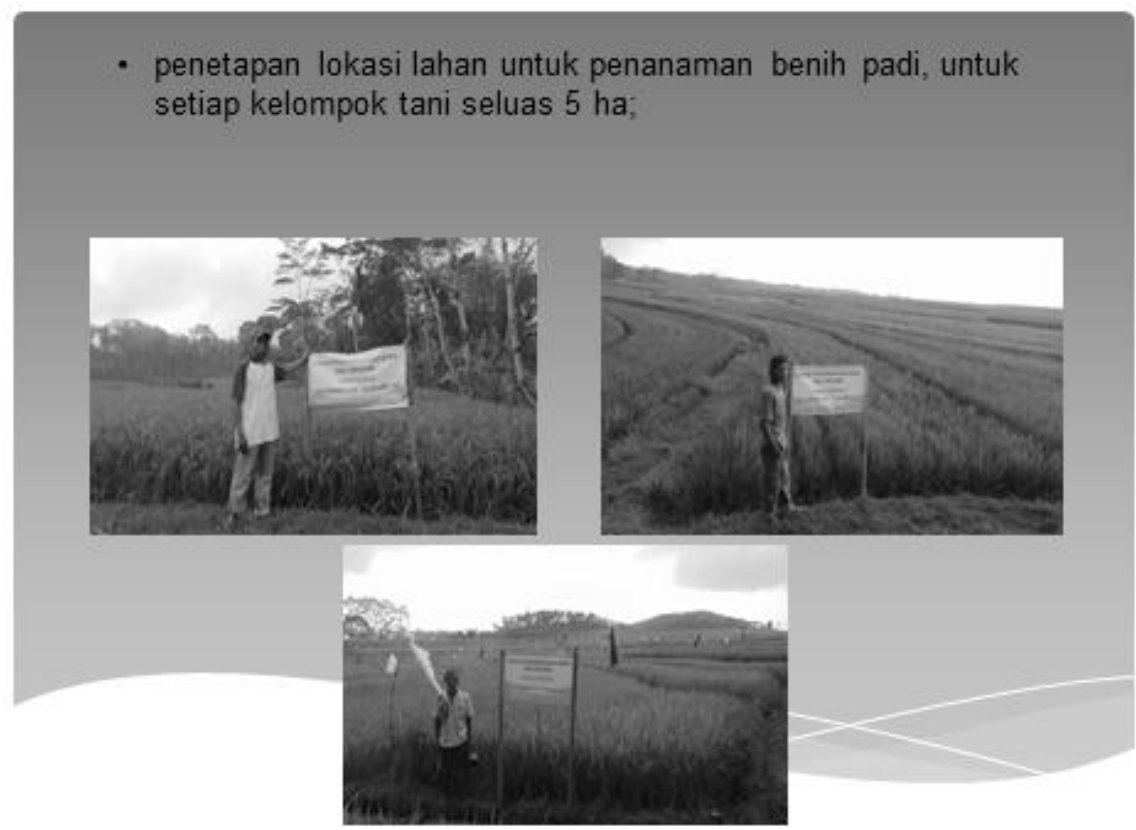

Gambar 4. Lahan penanaman benih padi organic 
4. Analisis Usaha Tani Benih Padi

\section{Organik}

Analisis

mempelajari

usahatani

bagaimana

seseorang

mengalokasikan

sumberdaya yang ada secara

efektif dan efisien untuk tujuan

memperoleh keuntungan pada

waktu tertentu. Disebut efektif

jika petani (produsen) dapat

mengalokasikan sumberdaya

yang mereka miliki dengan

sebaik-baiknya, serta dikatakan

efisien apabila pemanfaatan

tersebut menghasilkan output

yang melebihi input (Soekartawi,

2002). Boediono (1998),

menyatakan bahwa biaya

mencakup suatu pengukuran nilai

sumber daya yang harus

dikorbankan sebagai akibat dari

aktivitas-aktivitas

yang

bertujuan untuk mencari

keuntungan. Handoko (2001)

menjelaskan bahwa produksi

merupakan usaha-usaha

pengelolaan secara optimal

penggunaan sumberdaya seperti tenaga kerja, mesin-mesin, peralatan, bahan mentah, dan sebagainya, dalam proses transformasi bahan mentah dan tenaga kerja menjadi berbagai produk dan jasa. Penggunaan faktor produksi dalam setiap produksi barang dan jasa membutuhkan biaya-biaya untuk pembelian sumberdaya utama atau pendukung dalam produksi. 
Tabel 3. Analisis Usaha Tani untuk tujuan konsumsi

\begin{tabular}{|c|c|c|c|c|}
\hline \multirow{2}{*}{ No. } & \multirow{2}{*}{ Uraian } & \multicolumn{3}{|c|}{ Kelompok Tani } \\
\hline & & Al-Baroqah 3 & Walisongo & Al-Masroah \\
\hline 1 & Luas Lahan (Ha) & 1 & 1 & 1 \\
\hline 2 & Produksi (Kg/Ha) & 3.500 & 3.500 & 3.500 \\
\hline 3 & $\begin{array}{l}\text { Harga Satuan } \\
\text { Produksi (Rp/Kg) }\end{array}$ & 4.000 & 4.000 & 4.000 \\
\hline 4 & Nilai Produksi (Rp) & 14.000 .000 & 14.000 .000 & 14.000 .000 \\
\hline \multirow[t]{12}{*}{5} & Biaya Produksi & & & \\
\hline & a. Biaya Variabel & & & \\
\hline & $\begin{array}{l}\text { 1. Benih (Rp) (30 } \\
\text { kg x 12.500) }\end{array}$ & 375.000 & 375.000 & 375.000 \\
\hline & $\begin{array}{l}\text { 2. Pupuk (Rp) } \\
(2000 \mathrm{~kg} \mathrm{x} \\
1000)\end{array}$ & 2.000 .000 & 2.000 .000 & 2.000 .000 \\
\hline & $\begin{array}{l}\text { 3. Pestisida } \\
\text { organik (Rp) } \\
(10 \text { It x } \\
150.000)\end{array}$ & 1.500 .000 & 1.500 .000 & 1.500 .000 \\
\hline & $\begin{array}{l}\text { 4. Tenaga Kerja } \\
\text { (Rp) }\end{array}$ & 5.100 .000 & 5.100 .000 & 5.100 .000 \\
\hline & $\begin{array}{l}\text { Total Biaya } \\
\text { Variabel (Rp) }\end{array}$ & 8.975 .000 & 8.975 .000 & 8.975 .000 \\
\hline & b. Biaya Tetap & & & \\
\hline & $\begin{array}{l}\text { 1. Penyusutan } \\
\text { Alat (Rp) }\end{array}$ & 150.000 & 150.000 & 150.000 \\
\hline & $\begin{array}{l}\text { 2. Sewa Mesin } \\
\text { (Rp) }\end{array}$ & 750.000 & 750.000 & 750.000 \\
\hline & $\begin{array}{l}\text { 3. Sewa Lahan } \\
\text { (Rp) }\end{array}$ & 2.000 .000 & 2.000 .000 & 2.000 .000 \\
\hline & Total Biaya Tetap & 2.900 .000 & 2.900 .000 & 2.900 .000 \\
\hline 6 & $\begin{array}{l}\text { Total Biaya } \\
\text { Produksi (Rp) } \\
\end{array}$ & 11.875 .000 & 11.875 .000 & 11.875 .000 \\
\hline \multirow[t]{2}{*}{7} & $\begin{array}{l}\text { Pendapatan } \\
\text { Bersih (Rp) }\end{array}$ & 2.125 .000 & 2.125 .000 & 2.125 .000 \\
\hline & $\mathrm{R} / \mathrm{C}$ & 1,178947368 & 1,178947368 & 1,178947368 \\
\hline
\end{tabular}


Uji kelayakan usaha dengan menggunakan $\mathrm{R} / \mathrm{C}$ ratio usaha tani padi organik yang dibudidayakan, menunjukkan bahwa untuk tiga kelompok tani padi organik yang dibudidayakan mempunyai nilai $R / C$ Ratio sama. Kelompok tani Al-Barokah, Walisongo dan Al-Masroah menghasilkan produksi 3500 $\mathrm{Kg} / \mathrm{Ha}$ dengan nilai produksi $\mathrm{Rp}$. 14.000.000,- dan Pendapatan bersih Rp. 2.125.000,-. Tiga Kelompok tani mempunyai $\mathrm{R} / \mathrm{C}$ ratio yang sama yaitu dengan nilai 1,178947468 atau rata-rata $\mathrm{R} / \mathrm{c}$ ratio $>1$.

Kebutuhan benih bagi petani sangat penting. Saat ini untuk mendapatkan benih padi sangat sulit. Hasil padi diatas apabila digunakan 20\% untuk memenuhi kebutuhan benih sebesar (20\%) maka nilai $\mathrm{R} / \mathrm{C}$ ratio nya menjadi berikut ini : 
Tabel 4. Analisis usaha tani untuk tujuan benih padi

\begin{tabular}{|c|c|c|c|c|}
\hline \multirow{2}{*}{ No. } & \multirow{2}{*}{ Uraian } & \multicolumn{3}{|c|}{ Kelompok Tani } \\
\hline & & Al-Baroqah 3 & Walisongo & Al-Masroah \\
\hline 1 & Luas Lahan (Ha) & 1 & 1 & 1 \\
\hline \multirow[t]{7}{*}{2} & Produksi (Kg/Ha) & 3.500 & 3.500 & 3.500 \\
\hline & Untuk Konsumsi & 2.000 & 2.000 & 2.000 \\
\hline & $\begin{array}{l}\text { Harga satuan produksi } \\
(\mathrm{Rp} / \mathrm{Kg})\end{array}$ & 4.000 & 4.000 & 4.000 \\
\hline & & 8.000 .000 & 8.000 .000 & 8.000 .000 \\
\hline & Untuk Benih & 1.500 & 1.500 & 1.500 \\
\hline & $\begin{array}{l}\text { Harga satuan produksi } \\
(\mathrm{Rp} / \mathrm{Kg})\end{array}$ & 12.500 & 12.500 & 12.500 \\
\hline & & 18.750 .000 & 18.750 .000 & 18.750 .000 \\
\hline 3 & Nilai Produksi (Rp) & 26.750 .000 & 26.750 .000 & 26.750 .000 \\
\hline \multirow[t]{12}{*}{4} & Biaya Produksi & & & \\
\hline & a. Biaya Variabel & & & \\
\hline & $\begin{array}{l}\text { 1. Benih (Rp) ( } 30 \mathrm{~kg} \mathrm{x} \\
\text { 12.500) }\end{array}$ & 375.000 & 375.000 & 375.000 \\
\hline & $\begin{array}{l}\text { 2. Pupuk (Rp) (2000 kg } x \\
1000)\end{array}$ & 2.000 .000 & 2.000 .000 & 2.000 .000 \\
\hline & $\begin{array}{l}\text { 3. Pestisida organik (Rp) } \\
(10 \text { lt } \times 150.000)\end{array}$ & 1.500 .000 & 1.500 .000 & 1.500 .000 \\
\hline & 4. Tenaga Kerja (Rp) & 5.100 .000 & 5.100 .000 & 5.100 .000 \\
\hline & Total Biaya Variabel (Rp) & 8.975 .000 & 8.975 .000 & 8.975 .000 \\
\hline & b. Biaya Tetap & & & \\
\hline & 1. Penyusutan Alat (Rp) & 150.000 & 150.000 & 150.000 \\
\hline & 2. Sewa Mesin (Rp) & 750.000 & 750.000 & 750.000 \\
\hline & 3. Sewa Lahan (Rp) & 2.000 .000 & 2.000 .000 & 2.000 .000 \\
\hline & Total Biaya Tetap & 2.900 .000 & 2.900 .000 & 2.900 .000 \\
\hline 5 & Total Biaya Produksi (Rp) & 11.875 .000 & 11.875 .000 & 11.875 .000 \\
\hline \multirow[t]{2}{*}{6} & Pendapatan Bersih (Rp) & 14.875 .000 & 14.875 .000 & 14.875 .000 \\
\hline & $\mathrm{R} / \mathrm{C}$ & 2,252631579 & 2,252631579 & 2,252631579 \\
\hline
\end{tabular}


Total biaya produksi yang digunakan untuk budidaya padi pada kelompok tani Al-Barokah, Walisongo dan Al-Masroah yaitu sebesar Rp. 11.875.000/Ha. Total nilai produksi dari ketiga kelompok tani adalah Rp. 26.750.000,- . Hasil analisis data nilai produksi petani menjadi meningkat awalnya hanya $\mathrm{Rp}$. 14.000.000,- menjadi Rp. 26.750.000,- . Pada tabel analisis usaha tani untuk kebutuhan konsumsi, seluruh hasil produksi di analisis hanya untuk kebutuhan konsumsi saja. Tabel analisis usaha tani untuk konsumsi dan benih, sebesar $20 \%$ digunakan untuk kebutuhan benih. Berdasarkan tabel 3 dan 4 nilai produksi padi naik 2 kali lipat.

Pendapatan dalam usaha tani padi berasal dari pengurangan nilai produksi dengan total biaya produksi. Semakin besar biaya produksi dengan jumlah produksi tetap akan mengakibatkan penurunan tingkat pendapatan petani, atau sebaliknya jika biaya produksi tetap dan nilai produksi menurun maka akan terjadi penurunan tingkat pendapatan petani (Suratiyah, 2009).

Hasil pengamatan dilapangan menunjukkan bahwa Dengan adanya diversifikasi hasil, untuk tujuan konsumsi dan sumber benih maka nilai $\mathrm{R} / \mathrm{C}$ ratio meningkat hampir 100\% sehingga nilai omset meningkat lebih dari 100\%. Tiga kelompok tani menghasilkan total pendapatan bersih Rp. 14.875.000,- .

\section{PENUTUP}

Hasil kegiatan IbPUD yang dicapai adalah 1). Pengelompokan lahan padi organik yang ada di wilayah desa Ketapang Kecamatan Sususkan Semarang, yaitu 46.79 ha lahan organik murni, 52.84 ha lahan organik konversi 2 tahun dan 24.59 ha merupakan lahan konversi 1 tahun; 2). Penentuan benih padi 
organik, sebagai benih penjenis dan benih dasar yang dilakukan oleh kelompok tani (Al-Barokah, Walisongo dan Al-Mazroah) yaitu padi Mentik Wangi, Mentik Susu, dan Hitam Arang; 3). Penetapan lokasi lahan untuk penanaman benih padi, untuk setiap kelompok tani seluas 5 ha; 4). Peningkatan pendapat petani meningkat, awalnya hanya Rp. 2.125.000,menjadi Rp. 14.875.000,-

\section{UCAPAN TERIMA KASIH}

Kepada Direktorat Riset dan Pengembangan Masyarakat, Kemenristekdikti atas dukungan pendanaan IbPUD tahun anggaran 2017, dan Lembaga Penelitian \& Pengabdian Kepada Masyarakat UNS atas segala dukungan

\section{REFERENSI}

Atmojo, S.W. 2003. Peranan Bahan Organik Terhadap Kesuburan Tanah Dan Upaya Pengelolaannya. Makalah IImiah. Telah Disajikan pada Pidato Pengukuhan Guru Besar IImu Kesuburan Tanah Fakultas
Pertanian Universitas Sebelas Maret Surakarta. Dipresentasikan Dimuka Sidang Senat Terbuka Universitas Sebelas Maret Surakarta 4 Januari 2003 http://www.suntoro.staff.uns.ac.i d. Diunduh pada tanggal 5 Oktober 2009.

Cahyani, V.R. 2010. Peran Beneficial Microbiota Untuk Meningkatkan Daya Dukung Lahan Dan Mengoptimalkan Pertumbuhan Dan Hasil Tanaman Dalam Praktek Pertanian Organik. Pidato Pengukuhan Guru Besar. Bidang IImu Mikrobiologi Pertanian. Pada Fakultas Pertanian. Universitas Sebelas Maret. Disampaikan dalam Sidang Senat Terbuka, Universitas Sebelas Maret, Tanggal 26 Oktober 2010. Universitas Sebelas Maret. Surakarta.

Departemen Pertanian 2008. Pedoman Sertifikasi Produk Pangan Organik. Otoritas Kompeten Pangan Organik. KPO Indonesia.

FAO.(1999).Organik agriculture. Committee on Agriculture. bodies/coag/coag15/x0075e.htm . <akses 26 September2015>.

IASA. (1990). Planting The Future : A Source Guide to Sustainable Agriculture in The Third Word. Minneapolis.

Ife, J., Frank Tesoriero. 2008. Alternatif Pengembangan Masyarakat Di Era Globalisasi. Community Development. Diterjemahkan oleh: Sastrawan 
Manullang, Nurul Yakin dan M. Nursyahid. Pustaka Pelajar. Yogyakarta.

Iqbal, M., Edi Basuno., Gelar Satya Budi. 2007. Esensi Dan Urgensi Kaji Tindak Partisipatif Dalam Pemberdayaan Masyarakat Perdesaan Berbasis Sumberdaya Pertanian. Forum Penelitian Agro Ekonomi. Vol 25. No 2. Desember 2007. $\mathrm{Hal}$ : 73-88.

www.pse.litbang.deptan.go.id.

Diunduh pada tanggal 30 Maret 2011. Jam 11.25 WIB.

Kallas, Z., Teresa Serra, Jose M. Gil. 2009. Farmer's Objectives as Determinant Factors of Organic Farming Adoption. Paper prepared for presentation at the 113th EAAE Seminar " $A$ resilient European food industry and food chain in a challenging world", Chania, Crete, Greece. date as in: September 3-6, 2009 www.ageconsearch.umn.edu. Diunduh pada tangga 10 Desember 2010. Jam 09.34 WIB. Mardikanto, T. 2010. Konsep-Konsep Pemberdayaan Masyarakat. Acuan Bagi Aparat Birokrasi, Akademisi, Praktisi dan Peminat/Pemerhati

Pemberdayaan Masyarakat. UNS Press. ISBN 979-978-563-5. Universitas Sebelas Maret. Surakarta.

Oleas, C., Dooley, K.E., Shinn, G.C., Giusti, C. 2010. A case study of the diffusion of agricultural innovations in Chimaltenango. Guatemala.
Journal of International Agricultural and Extension Education. Vol 17. No 2. Hal: 3345. (Abstr). ISSN: 10770755. www.scopus.com. Diunduh pada tanggal 18 September 2013. Jam 20.44 WIB.

Permentan No: 64/Permentan/OT.140/ 5/2013. Tentang Sistem Pertanian Organik. Tanggal 29 Mei 2013. Diundangkan di Jakarta pada Tanggal 3 Juli 2013. Menteri Hukum Dan Hak Asasi Manusia Republik Indonesia.

Reijntjes, C., Bertus Haverkort, Water Bayer. 1992. Pertanian Masa Depan. Pengantar Untuk Pertanian Berkelanjutan Dengan Input Luar Rendah. Diterjemahkan Oleh: Y Sukoco. Kanisius. Yogyakarta.

Sharifi, O., Sayed Abolhasan Sadati, Farahnaz Rostami Ghobadi, Sayed Abolghasem Sadati, Yaser Mohamadi, Parastoo Taher Tolou Del. 2010. Barriers to Conversion To Organic Farming: A Case Study In Babol County In Iran. African Journal of Agricultural Research. Vol 5 (16). Hal: 2260-2267. 18 Agustus 2010. ISSN 1991637X@2010 Academic Journals. www.academicjournals.org.

Diunduh pada tanggal 14 Desember 2010. Jam 10.36 WIB.

Soetomo. 2009. Pembangunan Masyarakat Merangkai Sebuah Kerangka. Pustaka Pelajar. Yogyakarta. 


\section{BIODATA PENELITI}

Dr. Ir. Supriyadi, M.P.

Tenaga Pendidik atau dosen di program studi Ilmu Tanah Fakultas Pertanian Universitas Sebelas Maret. Lulusan S2 Universitas Gadjah Mada Yogyakarta Tahun 1995 dan S3 Universitas Brawijaya Malang pada tahun 2001. Saat ini menjabat sebagai koordinator Pengabdian pada Masyarakat pada Unit Pengaduan dan Penjaminan Mutu Penelitian dan Pengabdian pada Masyarakat LPPM UNS. Pengalaman Penelitian dan pengabdian pada masyarakat diantaranya Peningkatan Pendapatan Kelompok Tani Padi Organik Melalui Program Mandiri Benih Di Desa Ketapang Kecamatan Susukan Semarang. 